JOURNAL OF INFORMATICS AND TELECOMMUNICATION ENGINEERING

Available online http://ojs.uma.ac.id/index.php/jite

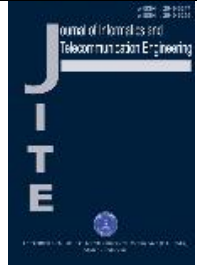

\title{
Model Identifikasi dan Analisis Risiko Rantai Pasok Agroindustri Kopi Gayo dengan Pendekatan Fuzzy Analytichal Hierarchy Process
}

\section{Model of Risk Identification and Supply Chain Analysis of Gayo Coffee Agroindustry with Fuzzy Analytichal Hierarchy Process Approach}

\author{
Muhamad Yustisar* \\ Universitas Gajah Putih Takengon, Indonesia \\ *E-mail Korespondensi: yustisar270267@gmail.com
}

\begin{abstract}
Abstrak
Kopi Gayo merupakan salah satu komoditi pertanian utama provinsi Aceh selain kopi, nilam, pinang dan kelapa sawit. Upaya mencapai rantai pasok yang berkelanjutan, perlu diperhatikan tiga aspek yang menjadi pilar yaitu ekonomi, sosial dan lingkungan. Manajemen rantai pasok pertanian terutama kopi Gayo umumnya lebih sulit ditangani dibandingkan dengan produk manufaktur karena produk pertanian memiliki sifat cepat rusak, ukuran bervariasi, musiman, lokasi tersebar dan skala kecil, sehingga sangat rentan terhadap risiko kerugian bagi pelakunya. Fakta saat ini menunjukkan bahwa beberapa aspek belum menunjukkan kondisi keberlanjutan, seperti pada indikator profit usaha petani, keterampilan pelaku, penggunaan air pada proses produksi jauh di atas ambang batas, pengelolaan risiko rantai pasok serta pola hubungan keterkaitan antar pelaku. Tujuan dari penelitian ini mengetahui faktor-faktor risiko yang paling berpengaruh dan analisis interaksi antar pelaku untuk bersama-sama mengelola risiko dalam struktur rantai pasok kopi Gayo. Metode yang digunakan adalah sintesis logika Fuzzy Analytichal Hierarchy Process (F-AHP) dan proses hirarki analitik, sedangkan analisis interrelasi dilakukan secara deskriptif. Hasil Fuzzy AHP menunjukkan bahwa pada petani, risiko terbesar adalah mutu dan budidaya, pada pedagang pengepul adalah pemenuhan mutu dan harga, pada agroindustri risiko terbesar adalah mutu dan harga.
\end{abstract}

Kata Kunci: Agroindustri Kopi Gayo; Fuzzy Analytichal Hierarchy Process; Risiko Rantai Pasok

\begin{abstract}
Gayo coffee is one of the main agricultural commodities of Aceh province besides coffee, patchouli, areca nut and palm oil. Efforts to achieve a sustainable supply chain, it should be noted three aspects that become pillars of economic, social and environmental. Agricultural supply chain management especially Gayo coffee is generally more difficult to handle than manufactured products because agricultural products have rapidly damaged properties, varied size, seasonal, scattered locations and small scale, making it very susceptible to the risk of harm to the perpetrators. The current facts show that some aspects have not demonstrated sustainability conditions, such as farmers' profitability indicators, skills of actors, water use in production processes far above thresholds, supply chain risk management and patterns of interrelationship between actors. The purpose of this research is to know the most influential risk factors and interaction analysis among actors to jointly manage risk in Gayo supply chain structure. The method used is Fuzzy Analytichal Hierarchy Process (F-AHP) logic synthesis and analytic hierarchy process, while interrelation analysis is done descriptively. Fuzzy AHP results show that in farmers, the greatest risk is quality and cultivation, in traders collectors are the fulfillment of quality and price, the largest risk agroindustry is the quality and price.
\end{abstract}

Keywords: Gayo Coffee Agroindustry; Fuzzy Analytichal Hierarchy Process; Supply Chain Risk 


\section{PENDAHULUAN}

Saat ini, permasalahan pada pelaksanaan proses agroindustri kopi Gayo, Provinsi Aceh adalah berupa rendahnya pemenuhan mutu, produktivitas, gap harga jual produk antara petani dan eksportir yang terlalu jauh dalam kerangka rantai pasok, serta disinformasi permintaan antar pelaku (Jaya et al., 2013), sehingga masalah tersebut dapat menimbulkan risiko terhadap mutu, harga, pasokan, permintaan dan budidaya pada pelaku petani, pedagang pengepul dan agroindustri kopi, yang secara keseluruhan berpengaruh terhadap daya saing kopi Gayo. Untuk mengantisipasi risiko tersebut diperlukan suatu penanganan, sehingga dampak risiko tersebut dapat dikurangi.

Risiko mutu buah kopi yang dihasilkan petani, yang disebabkan oleh tidak seragamnya tingkat kematangan, teknik panen stripping, dan penanganan pasca panen yang kurang baik sehingga tingginya kontaminan fisik, dimana hal tersebut bertentangan dengan SNI 012907 tahun 2008.

Risiko pasokan bahan baku, karena dalam satu tahun produksi kopi berkisar enam sampai delapan bulan (umumnya Bulan Oktober-Juni), walaupun terdapat musim panen raya yaitu pada sekitar Bulan Desember sampai Januari, sedangkan permintaan kopi biji yang diterima pabrik cenderung stabil (Silitonga, 2008). Kapasitas mutu dan pasokan memegang peranan penting dalam pengukuran kinerja produksi karena menyangkut kecepatan respon terhadap permintaan konsumen yang diwujudkan dalam fleksibilitas, lead times dan kemampuan penyampaian baik kualitas, kuantitas dan time-delivery (Jodlbauer, 2008).

Rantai pasok merupakan kegiatan yang sangat penting dalam suatu sistem agroindustri, kegiatan tersebut mencakup pengadaan bahan baku, pengolahan, dan jaringan distribusi (Shafiro, 2001; Chopra, 2003; Van der vorst, 2004; Chopra dan Meindl, 2007; Adhitya, et al., 2009). Walaupun dalam pelaksanaannya, kegiatan rantai pasok pada agroindustri sangat kompleks, karena komoditi pertanian memiliki keterbatasan yaitu mudah rusak (perisable), musiman (seasonal), beragamnya mutu panen (high variety) dan kamba (bulky) sehingga sangat sulit dalam menggelolanya dibandingkan dengan industri manufaktur (Widodo, et al., 2004; Apaiah dan Hendrix, 2005).

Pengelolaan risiko rantai pasok adalah suatu kegiatan yang terkoordinasi diantara seluruh partner (Tang, 2006; Xia and Chen, 2010) dan secara umum menyangkut isu risiko penyimpangan yang potensial terjadi (disruption risk) pada seluruh rangkaian proses produksi (time to table). Untuk mencegah atau mengurangi akibat yang ditimbulkan oleh risiko tersebut, diperlukan penyusunan skenario penanganan tepat berdasarkan spesifikasi risiko dari struktur rantai pasok, dalam hal ini adalah risiko rantai pasok kopi Gayo.

Untuk mencapai tujuan pengelolaan rantai pasok kopi Gayo yang dapat meminimalkan risiko yang ditanggung oleh masing-masing pelaku, diperlukan suatu analisis yang mendalam. Beberapa penelitian dengan topik pengelolaan risiko rantai pasok pertanian telah dilakukan, 
diantaranya Astuti et al. (2012), Hidayat et al. (2012), Fitrianto dan Hadi (2012). Sedangkan secara khusus penelitian yang membahas rantai pasok kopi telah dilakukan oleh Adam dan Ghaly (2007), MacDonald (2007) dan Rachman Jaya, Machfud, Raharja, Sapta, Marimin. (2014).

Berdasarkan uraian di atas, dapat dikatakan bahwa permasalahan pengelolaan risiko rantai pasok kopi Gayo masih belum efektif, yaitu dalam hal bagaimana mengurangi dampak risiko secara bersama, sehingga diperlukan kajian yang mendalam berupa identifikasi, analisis faktor-faktor dan penyusunan skenario penanganan risiko rantai pasok kopi Gayo.

Tujuan penelitian ini adalah untuk mengetahui faktor-faktor risiko yang terjadi pada rantai pasok agroindustri kopi Gayo dan menganalisis interaksi antar pelaku untuk bersama-sama mengelola risiko tersebut.

Identifikasi risiko dilakukan sebagai langkah awal dalam menyeimbangkan risiko yang terjadi pada rantai pasok. Penilaian risiko menjadi suatu hal yang sangat vital untuk perancangan proses rantai pasok untuk mendapatkan nilai tambah yang seimbang. Pembagian keuntungan dan risiko yang seimbang pada pelaku rantai pasok merupakan aktivitas penting yang harus dianalisa dalam rantai pasok (Fu, 2012).

Risiko adalah kemungkinan terjadinya penyimpangan dari harapan yang dapat menimbulkan kerugian, sedangkan manajemen risiko adalah usaha yang secara rasional ditujukan untuk mengurangi kemungkinan terjadinya kerugian dari risiko yang dihadapi (Harland, 2003).
Identifikasi risiko merupakan tahapan yang penting dalam manajemen risiko rantai pasok dan harus melibatkan para pelaku rantai pasok. Identifikasi risiko pada rantai pasok agroindustri kopi dilakukan mulai dari identifikasi risiko di tingkat petani, pengepul maupun industri pengolahan kopi. Adapun risiko yang terjadi dalam rantai pasok diantaranya yaitu kualitas, keterlambatan pengiriman, peningkatan biaya, lamanya lead time dan keterbatasan kapasitas, sehingga pendekatan terhadap proses identifikasi risiko lebih diutamakan pada sisi kualitas dan kuantitas pasokan, waktu serta biaya.

\section{METODE PENELITIAN}

Pokok bahasan dalam penelitian ini sesuai dengan tujuan penelitian adalah mengetahui faktor-faktor risiko apa saja yang paling berpengaruh terhadap rantai pasok kopi Gayo dan menganalisis interaksi antar pelaku untuk bersamasama mengelola risiko tersebut. Untuk mencapai tujuan tersebut dalam pelaksanaan diwujudkan ke dalam rancangan kegiatan berikut.



Gambar 1. Rancangan Kegiatan Risiko Rantai Pasok Kopi Gayo 


\section{Muhamad Yustisar, Model Identifikasi dan Analisis Risiko Rantai Pasok Agroindustri}

Tahapan penelitian dimulai dengan identifikasi faktor-faktor yang berpengaruh terhadap risiko pasok kopi Gayo, kemudian membuat struktur hirarki, membuat kuesioner, survei pakar dan analisis data. Tahapan analisis data dalam fuzzy mencakup fuzzyfikasi, agregasi, menghitung konsistensi rasio dan defuzzyfikasi (Nepal et al., 2010). Sedangkan analisis interrelasi dilakukan secara deskriptif.

Analisis Identifikasi Risiko Rantai Pasok Kopi Gayo

Identifikasi risiko rantai pasok kopi Gayo adalah proses identifikasi faktorfaktor risiko yang berpengaruh pada sistem rantai pasok kopi Gayo. Pada penelitian ini identifikasi risiko rantai pasok dilakukan dengan menggunakan Fuzzy-AHP. Adapun tahapan analisis identifikasi risiko rantai pasok adalah sebagai berikut:

Penyusunan Hirarki

Tahapan penyusunan hirarki dalam Analitical Hierarcy Process (AHP) pada penelitian ini terdiri dari identifikasi faktor-faktor risiko yang berpengaruh terhadap rantai pasok kopi Gayo, menyusun struktur hirarki, pembuatan kuesioner, pengumpulan data, agregasi pendapat pakar, membuat matriks kriteria dan alternatif, menghitung bobot kriteria dengan metode pairwise comparison, menghitung nilai eigen alternatif, menghitung konsistensi rasio, menghitung skor akhir, merangking berdasarkan skor akhir dan penarikan kesimpulan (Suharjito, 2011; Hidayat et al., 2012).
Responden Penelitian

Pemilihan responden berdasarkan purposive sampling didapat sebanyak 5 orang pakar mewakili kalangan akademisi, peneliti dari lembaga penelitian perkopian dan praktisi usaha kopi Gayo.

\section{Fungsi Keanggotaan Fuzzy}

Fungsi keanggotaan adalah kurva yang menunjukkan pemetaan nilai input ke dalam nilai-nilai keanggotaan, dalam hal ini dengan interval antara 0 dan 1 (Suharjito, 2011). Untuk memetakan nilai-nilai keanggotaan tersebut dapat dilakukan dengan melalui suatu fungsi. Dalam penelitian ini fungsi keanggotaan fuzzy yang digunakan adalah Triangular Fuzzy Number (TFN). Adapun rumus fungsi keanggotaan fuzzy TFN sebagai berikut.

$\mu(x)= \begin{cases}0 & ; \text { jika } x \leq a \text { atau } x \geq c \\ (x-a) /(b-a) & ; \text { jika } a \leq x \leq b \\ (c-x) /(c-b) & ; \text { otherwise }\end{cases}$

\section{Fuzzyfikasi}

Fuzzyfikasi pada metode Fuzzy-AHP adalah, proses pengubahan nilai selang rating (berupa batas nilai) yang diberikan oleh penilai menjadi selang dalam bentuk bilangan fuzzy (Marimim, 2009). Nilai input bilangan fuzzy untuk setiap level menggunakan TFN. TFN dipilih karena memiliki nilai keanggotaan penuh, yaitu satu tunggal berada pada puncak segitiga untuk nilai batas tengah (BT), sedangkan pada nilai-nilai lainnya, fungsi keanggotaannya lebih besar dari nol $(>0)$ untuk batas bawah (BB) dan lebih kecil dari satu $(<1)$ untuk batas atas (BA). Dengan demikian maka keraguan narasumber diarahkan kepada keyakinan di nilai BT. Tiga nilai batas pada skala yaitu BB, BT dan BA dari setiap data masukan adalah sebagaimana Tabel 1. 
Tabel 1. Skala TFN dalam Fuzzy-AHP

\begin{tabular}{clcl}
\hline No & \multicolumn{1}{c}{ Skala linguistik fuzzy berpasangan } & Skala TFN & \multicolumn{1}{c}{ Resiprokal TFN } \\
\hline 1 & Kedua faktor sama pentingnya terhadap tujuan & $(1,1,3)$ & $(1 / 3,1,1)$ \\
3 & Salah satu faktor sedikit lebih penting dari yang lain & $(1,3,5)$ & $(1 / 5,1 / 3,1)$ \\
5 & Salah satu faktor lebih penting dari yang lain & $(3,5,7)$ & $(1 / 7,1 / 5,1 / 3)$ \\
7 & Salah satu faktor sangat lebih penting dari yang lain & $(5,7,9)$ & $(1 / 9,1 / 7,1 / 5)$ \\
9 & Salah satu faktor mutlak lebih penting dari yang lain & $(7,9,9)$ & $(1 / 9,1 / 9,1 / 7)$ \\
\hline
\end{tabular}

Sumber: Kulak dan Kahraman (2005)

Berdasarkan Tabel 1, terlihat bahwa pada skala TFN $(1,1,3)$ memiliki nilai resiprokal $\quad(1 / 3,1,1) \quad$ yang mempresentasikan suatu nilai dalam fungsi keanggotaan fuzzy. Resiprokal mencerminkan perbandingan terbalik dari nilai tersebut, dalam hal ini nilai keanggotaan fuzzy bergerak dari nilai kecil ke besar (0-10). Kulak dan Kahraman (2005).

\section{Agregasi}

Agregasi adalah proses penyatuan skor dari beberapa input untuk mencapai suatu nilai tunggal, dalam hal ini input dari beberapa pakar. Agregasi pendapat pakar dilakukan dengan rata-rata geometrik untuk batas bawah, batas tengah dan batas atas dari ketiga kelompok masukan (Bozbura et al., 2007). Luaran langkah ini masih berupa nilai fuzzy.

\section{Defuzzyfikasi}

Defuzzyfikasi adalah penentuan satu nilai tunggal (crisp) dari skor fuzzy hasil inputan tahap sebelumnya. Defuzzyfikasi merupakan suatu proses pengubahan output fuzzy ke output yang bernilai tunggal (crisp). (Marimin, 2009). Pada penelitian ini teknik defuzzyfikasi yang digunakan adalah centroid, yaitu nilai tunggal dari variabel output yang dihitung dengan menemukan nilai variabel dari center of gravity, berupa suatu fungsi keanggotaan untuk nilai dari fuzzy (Mikhailov, 2004: Alavi, 2012).

\section{HASIL DAN PEMBAHASAN}

Struktur Rantai Pasok

Jaringan rantai pasok kopi Gayo dimulai dari petani. Aktivitas petani mencakup usaha budidaya yang berupa kegiatan persiapan lahan, pembibitan, penanaman, pemeliharaan sampai panen. Produk akhir yang dihasilkan adalah kopi gelondongan merah (cerry). Berdasarkan hasil observasi lapang permasalahan utama tingginya risiko budidaya, khususnya serangan hama dan penyakit.

Pelaku selanjutnya adalah pedagang pengepul dengan aktivitas pembelian kopi gelondongan merah dari petani, melakukan pulper dan pengeringan primer sampai kadar air 22\% dengan metode wet processing. Produk akhir pedagang pengepul adalah kopi hard skin (HS). Pelaku terakhir adalah agroindustri kopi yang umumnya bertindak sebagai eksportir, dengan aktivitas utama adalah pembelian kopi HS dari pedagang pengepul, hulling, pengeringan biji kopi sampai kadar air 12\%, pengemasan, penyimpanan dan penjualan ke buyer di negara tujuan ekspor. 
Identifikasi Risiko Rantai Pasok Kopi Gayo

Identifikasi risiko bertujuan untuk mengetahui faktor-faktor risiko apa saja yang mempengaruhi kinerja rantai pasok kopi Gayo. Tahap awal pemodelan adalah menentukan struktur hirarki, yang kenudian ditelaah oleh pakar yang terlibat, dan selanjutnya dilakukan analisis dengan pendekatan fuzzy terhadap input data.
Keluaran dari model adalah diketahuinya nilai tunggal (crips) bobot risiko masing-masing faktor risiko, aktor dan tujuan (Tabel 2). Struktur hirarki terdiri dari tujuan dengan tiga aspek yaitu pemenuhan aspek mutu, jumlah dan time delivery. Bobot masing-masing tujuan disajikan pada Tabel 3.

Tabel 2. Hasil pembobotan faktor risiko masing-masing pelaku rantai pasok kopi Gayo

\begin{tabular}{lccccc}
\multicolumn{1}{c}{ Pelaku } & Risiko Mutu & Risiko Harga & $\begin{array}{c}\text { Risiko } \\
\text { Budidaya }\end{array}$ & $\begin{array}{c}\text { Risiko } \\
\text { Permintaan }\end{array}$ & $\begin{array}{c}\text { Risiko } \\
\text { Pasokan }\end{array}$ \\
\hline Petani & 0,31 & 0,26 & 0,3 & 0,13 & \\
Pedagang pengepul & 0,45 & 0,24 & & 0,18 & 0,12 \\
Agroindustri & 0,31 & 0,30 & & 0,26 & 0,13 \\
\hline
\end{tabular}

Berdasarkan Tabel 2 terlihat bahwa, pada masing-masing pelaku memiliki faktor risiko yang berbeda, hal ini terjadi karena masing-masing pelaku memiliki aktivitas yang berbeda pula. Pada level petani risiko mencakup mutu, harga, budidaya dan permintaan. Hasil analisis menunjukkan bahwa risiko tertinggi pada risiko mutu dengan bobot $(0,31)$ dan budidaya $(0,30)$. Bobot ini mencerminkan faktor mutu sangat penting terutama dalam sistem perdagangan global.

Pada level pedagang pengepul resiko tertinggi berada pada komponen mutu $(0,45)$ dan harga $(0,24)$. Bobot ini dapat mencerminkan bahwa pelaku pengepul harus fokus pada aspek ini. Hal ini disebabkan karena tingginya cemaran fisik (ranting dan kerikil) serta kadar air (di atas 18\%).Pada level agroindustri kopi, risiko tertinggi adalah mutu $(0,31)$ dan harga $(0,30)$. Hal ini disebabkan parameter mutu erat hubungannya dengan pasokan kopi HS dari pedagang pengepul, dimana cemaran fisik masih tinggi akibat proses penjemuran yang dilakukan di tempat terbuka, sedangkan parameter harga berhubungan erat dengan fluktuasi harga kopi di dunia, selain itu kontrak dengan buyer, berlaku hanya 1 tahun, sehingga risiko ketidakpastian harga sangat tinggi.

Tabel 3. Pembobotan tujuan dan pelaku rantai pasok kopi Gayo

\begin{tabular}{lclc}
\hline \multicolumn{1}{c}{ Tujuan } & Bobot & \multicolumn{1}{c}{ Pelaku } & Bobot \\
\hline Pemenuhan mutu & 0,41 & Petani & 0,52 \\
Pemenuhan jumlah & 0,30 & Pedagang Pengepul & 0,13 \\
Time-delivery & 0,29 & Agroindustri & 0,35 \\
\hline
\end{tabular}

Berdasarkan Tabel 3 terlihat bahwa, pada elemen tujuan bobot tertinggi terdapat pada pemenuhan mutu $(0,41)$, kemudian pemenuhan jumlah $(0,30)$ dan time-delivery $(0,29)$. Hal ini menunjukkan bahwa dalam perdagangan global, parameter mutu merupakan komponen utama yang harus dipenuhi oleh pelaku. Parameter mutu dipengaruhi oleh aspek budidaya, panen dan pengolahan. 
Dari sisi pelaku, petani memiliki bobot tertinggi terdapat pada petani $(0,52)$, kemudian agroindustri $(0,35)$ dan pedagang pengepul $(0,13)$. Hal ini menunjukkan bahwa pelaku petani memiliki peran yang sangat besar dalam sistem rantai pasok kopi Gayo.

\section{SIMPULAN}

Kesimpulan penelitian ini adalah bahwa berdasarkan analisis Fuzzy-AHP, risiko utama dalam rantai pasok kopi Gayo adalah mutu, budidaya, harga, pasokan dan permintaan. Pada pelaku petani bobot tertinggi pada risko mutu dan budidaya, pelaku pedagang pengepul adalah risiko mutu dan harga, sedangkan pada pelaku agroindustri kopi adalah risiko mutu dan harga. Secara keseluruhan, rata-rata nilai tunggal (crips) risiko rantai pasok kopi Gayo termasuk dalam kategori sedang.

\section{DAFTAR PUSTAKA}

Adhitya, A., R. Srinivasan and I. Karimi. 2009. Supply Chain Risk Identification Using a Hazop-Based Approach. AIChE Journal, 55 (6): 1447-1463.

Alavi N, 2012. Quality Determination of Mozafati Dates using Mamdani Fuzzy Inference System. J Saudi Soc Agri Sci Article Inpress.

Apaiah, K. and E.M.T. Hendrix. 2005. Design of a Supply Chain Network for Pea-Based Novel Protein Foods. Journal of Food Engineering, 70:383-391

Chopra, S. 2003. Designing The Distribution Network In Supply Chain. Transportation Research Part E, 39: 123-140.

Chopra, S and P. Meindl. 2007. Supply Chain Management: Strategy, Planning, and Operation [third edition]. Prentice Hall, New Jersey

Fu, W., Construction and Application of ThreeLevel Supply Chain Coordination Model with Profit Sharing Contract, J. International Review on Computers and Software (I.RE.CO.S.). 7(5): 2639-2650, 2012

Harland C, Brenchley R, Walker H. 2003. Risk in Supply Networks", J Purchasing \& Supply Management, 1(1):51-62.
Hidayat, Syarif, Marimin, Suryani, Ani, Sukardi, Yani, Mohamad, 2012, Model Identifikasi Risiko dan Strategi Peningkatan Nilai Tambah pada Rantai Pasok Kelapa Sawit, Jurnal Teknik Industri, 14 (2): 89-96.

Jaya, Rachman. 2013. Model Pengelolaan Pasokan dan Risiko Mutu Rantai Pasok Kopi Gayo, Jurnal Teknologi dan Industri Pertanian Indonesia, 5 (3): 24.

Jaya, Rachman, Machfud, Raharja, Sapta, Marimin. 2014. Analisis dan Mitigasi Risiko Rantai Pasok Kopi Gayo Berkelanjutan dengan Pendekatan Fuzzy, Jurnal Teknologi Industri Pertanian, 24 (1): 61-71.

Jodlbauer, H. 2008. Time-continous Analytic Production Model for Service Level, Work in Process, Lead Time and Utilization. Int. Journal of Production Research, 46(7):17231744.

Kulak O, Kahraman C. 2005. Fuzzy Multi-Attribute Selection among Transportation Companies using Axiomatic Design and Analytic Hierarchy Process. Int. J Infor Sci. 1 (170): 191-210.

Marimin. 2009. Teori dan Aplikasi Sistem Pakar dalam Teknologi Manajerial. Bogor: IPB Pres

Mikhailov L, 2004. Group Prioritization in the AHP by Fuzzy Preference Programming Method. Comp Opr Rex 31: 293-301.

Nepal B, Yadav OM, Murat A. 2010. A Fuzzy-AHP Approach to Prioritization of Cs Attributes In Target Planning for Automotive Product Development. Expert Sys with Appli. 37: 6775-6786.

Silitonga, CM. 2008. Analisis Keunggulan Bersaing Kopi Arabika Gayo Organik di Indonesia. Tesis Universitas Terbuka, Medan.

Sriwana, Iphov Kumala. 2014. Identifikasi Risiko Rantai Pasok Agroindustri Kakao Menggunakan Fuzzy AHP, Jurnal Inovis, 10 (1): 10 - 18.

Suharjito, 2011. Pemodelan Sistem Pendukung Pengambilan Keputusan Cerdas Manajemen Risiko Rantai Pasok Produk/Komoditi Jagung, Disertasi. Bogor: Institut Pertanian Bogor.

Tang, C.S. 2006. Perspectives in Supply Chain Risk Management [Review]. Int. J. Production Economic, 103 : 451-488

Vorst JGAJ van der. 2004. Supply Chain Management: Theory and Practice. Di dalam: Camps, T., Diederen P., Hofstede GJ., Vosb. The Emerging World of Chain and Networks. Hoofdstuk:Elsevier

Widodo, K.H., H.Nagasawa, K.Morizawa and M.Ota. 2004. A Periodical Flowering-Harvesting Model for Delivering Agricultural Fresh Product. European Journal of Operational Research, Article In Press. 